\title{
APPLICATION OF GEOSPATIAL TECHNIQUES IN THE LOCATIONAL PLANNING OF HEALTH CARE CENTERS IN MINNA, NIGERIA
}

\author{
Oluwaseun Olubadewo-Joshua ${ }^{1}$ and Kenneth Michael Ugom ${ }^{1}$ \\ ${ }^{1}$ Department of Geography, Ibrahim Badamasi Babangida University, Lapai, Nigeria \\ Email : oluwaseuno@ibbu.edu.ng
}

Received:16 October 2018/Revised 21 December 2018/Accepted: 14 January 2019/ Published online: 27 January 2019

\begin{abstract}
Access to health care is an important component of an overall health system and a major indicator of growth. Health care planning and Geographic Information System (GIS) are two relevant fields that depend upon spatial data. GIS plays an essential role in helping public health organizations to understand population health and make decisions with the powerful tools and situation that GIS technology provides. The purpose of the study to investigated the spatial distribution of health care centers in Minna, Nigeria with a view to use Geographic Information System (GIS) technique in health care management and planning. The method is a qualitative research that is used in making decisions in order to have a strong understanding of government policies and programs. Beyond the many uses of a GIS in health applications, the greatest power of a GIS lies in its ability to integrate information from disparate sources. Traffic disturbances and poor road network were observed to be the major factors militating against effective health care facilities location in the study area.
\end{abstract}

Keywords: Geographic Information Systems, Healthcare, Planning, Remote Sensing, Research

\section{Introduction}

Health institutions are a measure of a nation's health advance (Gatrell and Elliott 2009). Every country has different capabilities in fulfilling the health access of its citizens. One of them is influenced by geographical conditions which then affect the infrastructure budget in each region is very different. Flat areas will be easy and inexpensive in the construction of health facilities, while mountainous areas require more funds. Health care is a government effort to create a society that is physically and mentally healthy. Health services are not only related to medical health but also spiritually. This is due to the importance of the balance between the two 
elements. So it requires facilities that are also balanced between the two elements. In addition to infrastructure, health services also include the availability of human resources in the health sector which includes doctors, nurses, midwives, medical records, and other health resources. The existence of human resources in the health sector is also often uneven because of the geographical conditions of a region that has mountainous topography or is far from a big city. Especially if the country's natural resources have low potential, so they cannot contribute to the country's income.

Health access is generally aimed at people with weak economies. This is because the health costs are not comparable to the income of the weak economic community. Geographical aspects often cause people to have minimal income. This can be caused by the minimal potential of natural resources or government policies that are too profitable for investors. So that investment activities do not have an impact on the community economy and regional development. Developed countries have access to better health than developing countries. This is due to developed countries first managing their human resources. Quality human resources will overcome geographical constraints, so that development runs efficiently (Law and Morris, 1998; W.H.O, 1998). However, if human resource development is ignored, geographic determinants will occur. Ogundare (1982) states that healthy food is a determinant of the quality of public health. But getting food requires high income, so not all regions can fulfill it.

Developing countries have a higher vulnerability to the possibility of people being affected. So that health is not only related to infrastructure but also related to accessibility. Barton and Isourou (2000) emphasize the importance of sustainable development in the health sector. This is because health is not only for the benefit of the current generation, but also to meet the interests of the next generation. In addition, sustainable development also means that environmental aspects must be considered.

Geographical Information Systems (GIS) are tools to help analyze needs related to territorial aspects (Burrough, 2001). The existence of GIS is very efficient because it makes it easier for people to use the application. GIS can also help map health facilities ideally by taking into account the factors that benefit the community (Wilkinson et al. 2006; Albert et al., 2000; Cromley and McLafferty, 2012).

Therefore, the ability of GIS in terms of health services will consider aspects of the population and affordability (Abubakar et al. 2008). Regions that have a high population, will be prioritized 
to get a closer distance to health facilities. In addition, accessibility of a region to health facilities will be built based on morphological aspects so that the funds needed are not too high.

\section{Method}

\subsection{Study Area}

Minna is situated in Northern Nigeria between latitude $9^{0} 38^{`} 50^{\prime \prime} \mathrm{N}$ to $9^{0} 40^{`} 30.51^{\prime \prime} \mathrm{N}$ and longitude $6^{0} 322^{`} 26^{`} \mathrm{E}$ to $6^{0} 377^{`} 2.51^{`} \mathrm{E}$, (Figure 1). It has an average elevation of $272 \mathrm{~m}$ above sea level.

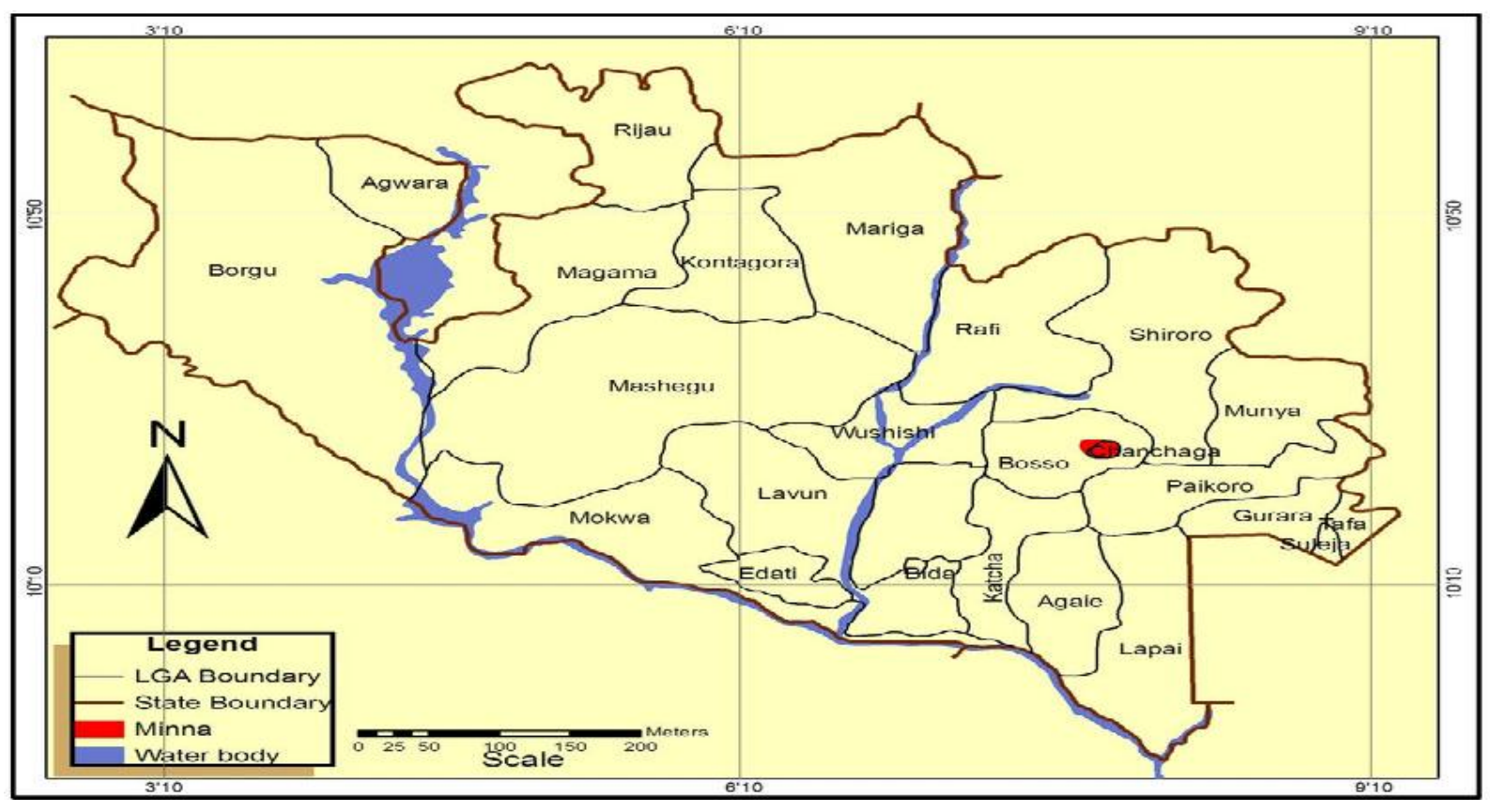

Figure 1: Map of Niger State showing Minna

Source: Ministry of Lands and Housing (2012)

\subsection{Data source}

Primary data in this study covers all the coordinates of health facilities. Secondary data in this study is the use of literature both from journals and other data. Digitalization is process is the conversion of analog data into digital data, so that it can be analyzed using GIS software. If this process does not work, the content contained in the application cannot be enabled.The georeferencing process is very important to meet the precision aspects of a GIS analysis. Without proper georeference, it can be ensured that all aspects of analysis will be wrong and cannot be 
used for the benefit of the community. In georeference there are 4 points that must be obtained through registration on the application screen. These 4 points will represent the entire area analyzed. Proximity analysis is an analysis that refers to the radius of a point against another point on the surface of the earth. In GIS, this analysis will be accommodated by buffer analysis. Furthermore, this analysis will give rise to the average distance of a region to the health center. The next analysis is query analysis which emphasizes the fastest search for points related to health facilities.

\section{Results and Discussion}

The results of the study can be seen in the following figure.

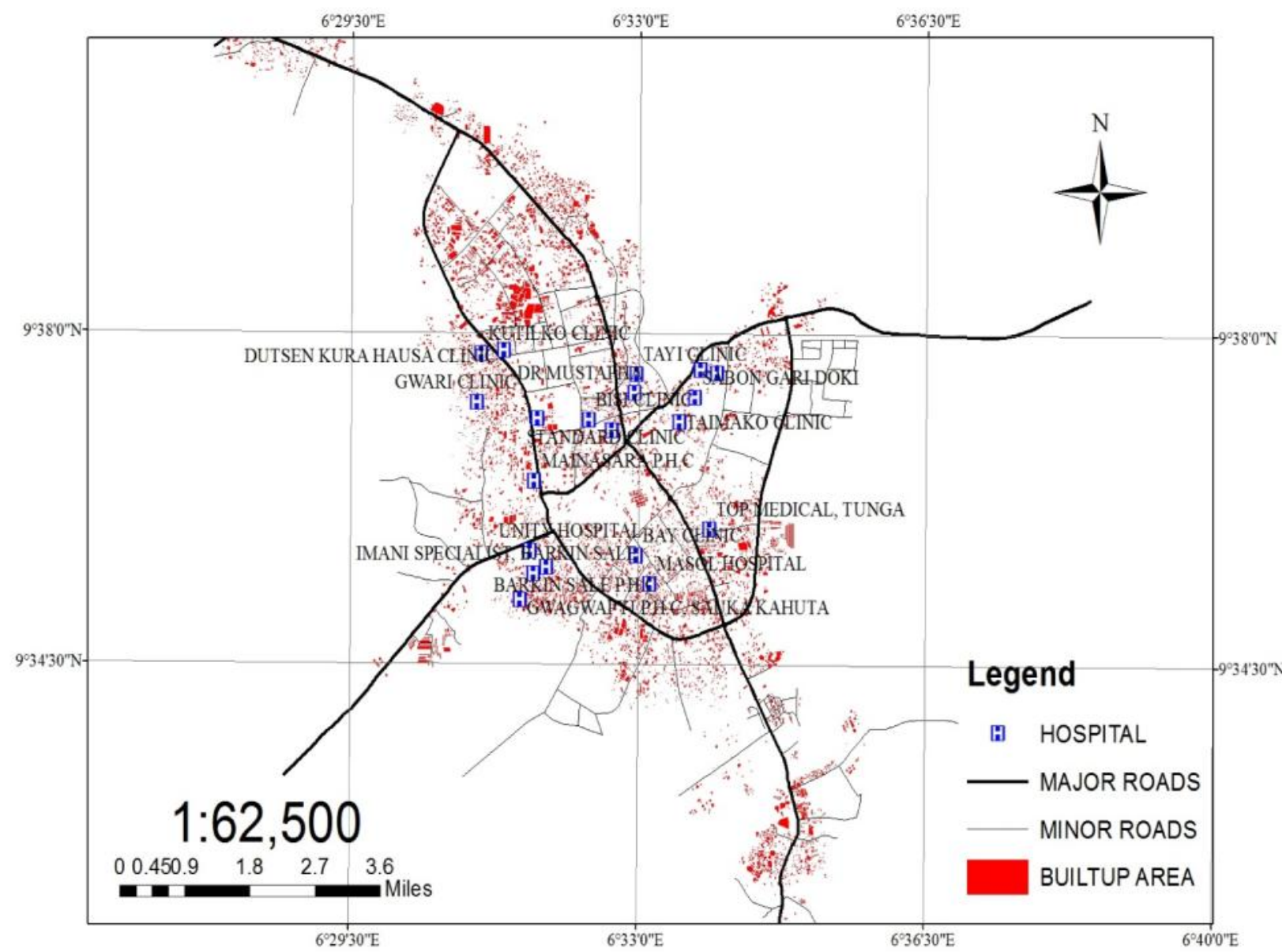

Figure 2: Map of Minna, showing the spatial distribution of health facilities 


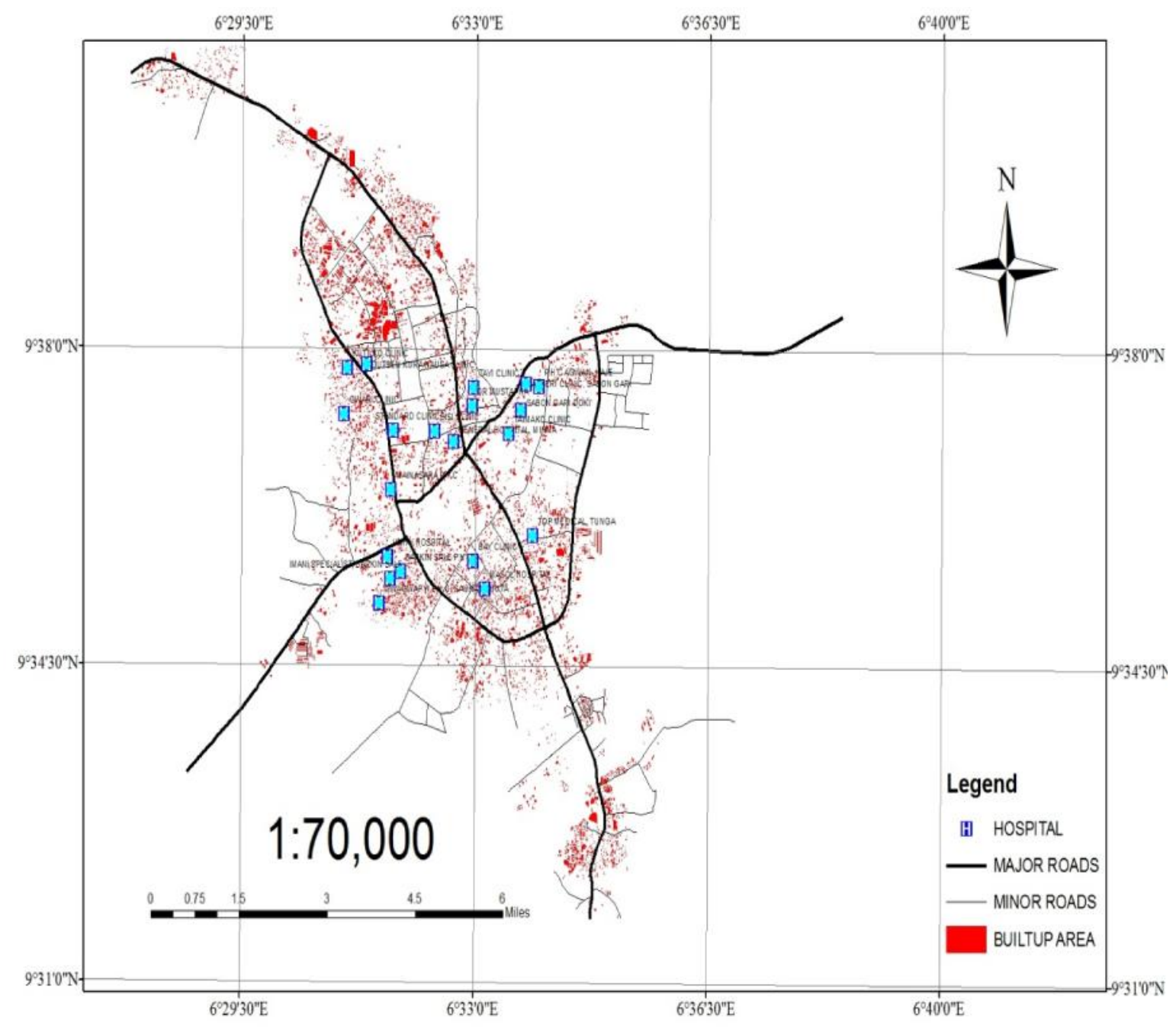

Figure 3: Proximity analysis from spatial query

If the index (Average Nearest Neighbor ratio) is less than 1, the pattern exhibits clustering. If the index is greater than 1 , the trend is toward dispersion. Results of the average nearest neighbor analysis showed an average nearest neighbor ratio of 1.120895. 
File Edit View Bookmarks Insert Selection Geoprocessing Customize Windows Help

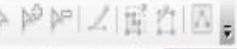

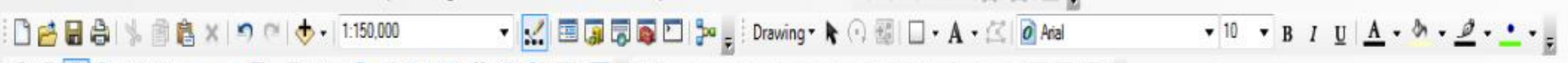

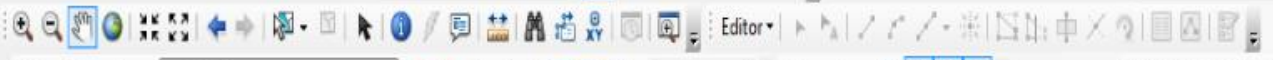

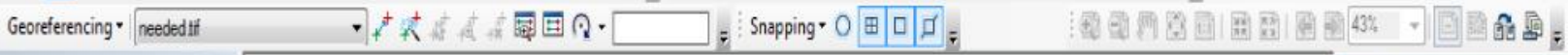

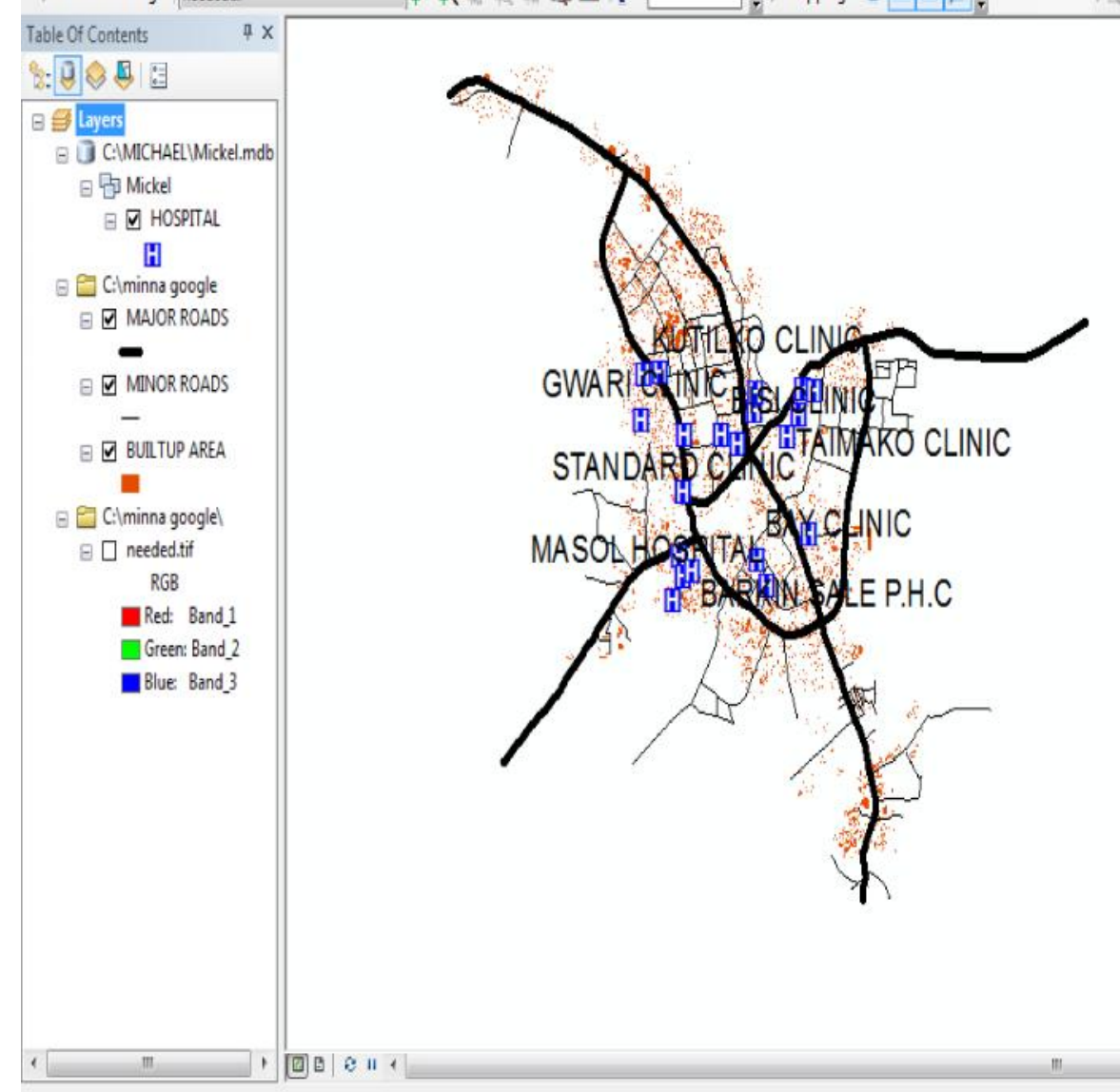

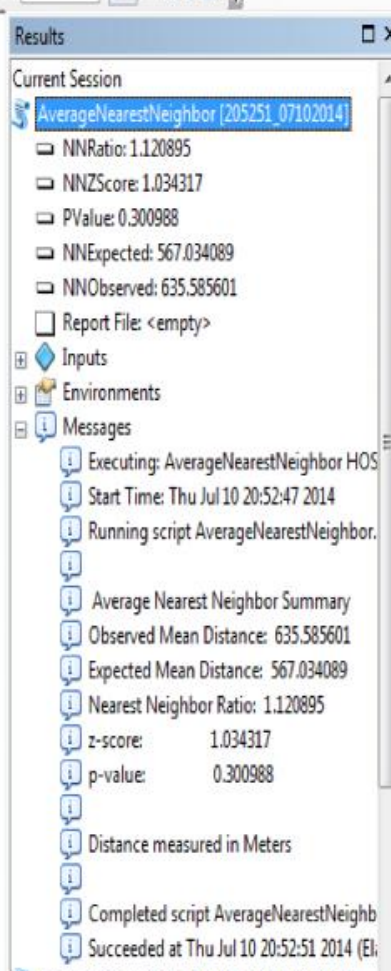

3. AverageNearestNeighbor [204759 07102014]

S PointDistance [204556_07102014]

用 Output Table Hospital PointDistance

[1] ArcToolbox KResults

Figure 4: Average nearest neighbor analysis from ArcGIS 


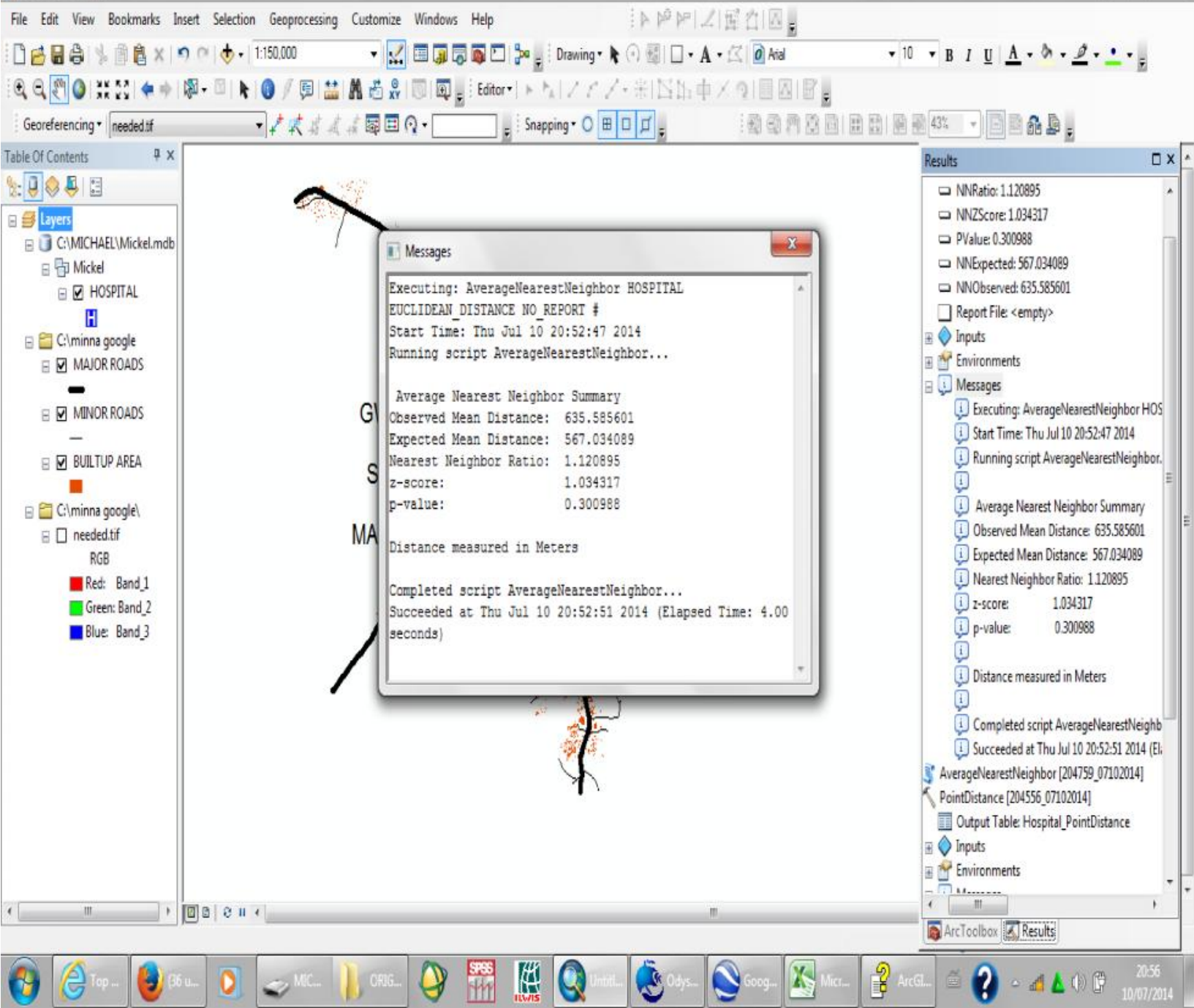

Figure 5: Average nearest neighbor analysis from Euclidean distance

Results from nearest neighbor analysis using Euclidean distance :

Observed Mean Distance: 635.585601

Expected Mean Distance: 567.034089

Nearest Neighbor Ratio: 1.120895

z-score:

1.034317

p-value:

0.300988

\section{Distance measured in Meters}


The results of the above research are in accordance with the results of the study (Dermatis et al, 2016, McLafferty, 2003 and The World Health Report, 2008) which state that distance will correlate strongly with transportation and accommodation costs. Population factors are the most important in determining the location of health facilities, the findings are supported by the results of the study (Chang, 2008) which states that a high population will potentially cause many disaster victims if a place is assumed to be a disaster-prone area.

Political factors and accessibility are ranked 2 in relation to location determination. This is in accordance with the results of the study (Abbas et. Al. 2012), which states that political factors are controlling in a region's development system. The results of the study indicate that the location points must also consider poverty. Regions with high poverty get priority to be close to health facilities. This is supported by research (Usman et. Al. 2013), which states that the poor are more susceptible to disease due to low income and unhealthy lifestyle. Differences in conditions between villages and cities often affect the construction of health facilities, this is because rural areas lack selling value compared to urban areas. This is in accordance with the results of the Lekan study (2010), which states that village and city disparities will influence government policies related to the construction of health facilities. Morphology is a very important aspect in calculating the cost of building health facilities. This is in accordance with the results of the study (Agaja, 2012) which states that the cost of building health facilities will be very different between the flat and mountainous regions.

\section{Conclusion}

Healthcare planning is a challenging field that depends on spatial data such as location and characteristics of health center demand. Today, health's planners have several tasks to cover to assure that health service is provided at the best location by using GIS. While GIS have been used to great success in the health industry, their full potential has not yet been reached. Beyond the many uses of a GIS in health applications, the greatest power of a GIS lies in its ability to integrate information from disparate sources. The ability to visually assess the locations of objects on the Earth's surface, rather than trying to interpret numbers on spreadsheets, is a key element leading to the use of a GIS. By integrating GIS into decision making, government stands the chance of making their health care facilities more functional and accessible to the populace. 


\section{References}

Abbas, I.I, Auta, S.Z and Na'iya, R.M (2012) Health Care Facilities Mapping and Database Creation Using GIS in Chikun Local Government, Kaduna State, Nigeria. Global Journal of Human Social Sciences (B) Vol. XII, Issue X, Version 1, pp 10-18

Abegunde, A. A. and Adedigba, A.M. (2011). Teaching Hospitals in African Nations: Infrastructure for Regional or Local Community Development? The African Symposium, Vol. 11, No. 2, pgs 49-59

Abubakar, M.S, Dalhatu, U. and Adamu M.Y (2008) Creating a GIS application for local health care planning in Nassarawa State. Indian Journal of Multidisciplinary Research; $4(4) 557-592$

Adejuyigbe, O. (1973), Location of Social Service Centres in Western Nigeria, The case of Medical Facilities, Man and Society. 1, 115-142

Agaja, S.A (2012) Spatial Distribution of Primary Health Care Centers in Ughelli South and Warri South Local Government Areas of Delta State, Nigeria. International Journal of Scientific and Technology Research. 1(9):38-41

Ajala, O.A., Sanni, L. and Adeyinka, S.A. (2005), Accessibility to Healthcare Facilities: A Panacea for Sustainable Rural Development in Osun State, South Western Nigeria. Journal of Human Ecology, 18(2), 121-128

Albert, D.P, Gesler, W.M and Levergood, B. (2000), Spatial Analysis, GIS, Remote Sensing applications in the Health Sciences. Ann Arbor Press, Chelsea, Michigan.

Andersen, R.M., (1995) "Revisiting the behavioral model and access to medical care, Journal of Health and Social Behavior, 36(1), 1-10

Arnoff, S. (1989), Geographic Information Systems: A Management Perspective. Ottawa, Ontario: WDL Publications

Ayeni B. (1987) Improving the Geographical Accessibility of Health Care Delivery Facilities in Rural Areas; A Nigerian case Study. Social Sciences and Medicine. Vol. 25 No. 10 pp. 1083-1094

Barton, H. and Isourou, C. (2000), Healthy Urban Planning. Spoon Press: WHO Regional Office for Europe

Burrough, P.A (2001), GIS and Geostatistics: Essential partners for spatial analysis. Environmental and Ecological Statistics, 8:361-377

Cromley, E.K and McLafferty, S.L (2012), GIS and Public Health. The Guilford Press, New York, London. $2^{\text {nd }} \mathrm{Ed}$

Chang, K. (2008), Introduction to Geographic Information Systems. Boston: McGraw Hill 
Densham, P.J. (1994) Integrating GIS and Spatial Modeling: Visual Interactive Modeling and Location Selection, Geographical Systems, 1(3), 203-219

Dermatis, Z., Tsoromokos, D., Gozadinos, F., and Lazakidou A. (2016) The utilization of Geographic Information System in Healthcare. International Journal of Health Research and Innovation. Vol. 4 No.1 pp39-57

Egunjobi, L. (1983) Factors Influencing the Choice of Hospitals: A Case study of the Northern part of Oyo State, Nigeria. Social Science and Medicine, Vol. 17, No.9, pp. 585-589

Fabiyi, S. (2001) Geographic Information Systems: Techniques and Methods RSS1, Ibadan

Frank, T. (2006) Methodology for optimizing location of new primary health care facilities in rural communities: A case study in KwaZulu-Natal, South Africa

Gatrell, A.C and Elliott, S.J (2009), Geographies of Health: An Introduction. Malden, MA: Wiley-Blackwell, $2^{\text {nd }}$ Ed.

Goldman, N. and Pebley, A.R. (1994) Health Cards, Maternal Reports and the Measurement of Immunization Leverage: the Example of Guatemala. Social Science and Medicine

Jimoh, H.I. and Azubike, J.O. (2012), The Roles of Geographic Information System on the Distributional Pattern of Health Care Facilities in Ilorin, Kwara State of Nigeria, International Journal of Social Science \& Education, Vol. 2 (2), 224-235

Joseph, A.E. and Philips, D.R. (1984) Accessibility and Utilization: Geographical perspective on Health Care Delivery; London, Harper and Row

Kalogirou, S. and R. Foley (2006), Health, Place and Hanly: Modeling Accessibility to Hospitals in Ireland. Irish Geography, 39 (1), pp. 52-68

Knox, P.L. (1979), The Accessibility of Primary Care to Urban Patients: A Geographical Analysis. British Journal of General Practice, 29, pp. 160-168

Kufoniyi, O. (1998) Education requirements in Geospatial Information Technology, Proceedings of the Workshop on Surveying and Spatial Information Technology, University of Lagos, Nigeria, 13p

Law, M.R and Morris, J.R (1998) Why is mortality higher in poorer and in more Northern areas of England and Wales? Journal of Epidemiology Community Health, 52:344-352

Lekan, S. (2010), Distributional Pattern of Healthcare Facilities in Osun State, Nigeria. Ethiopian Journal of Environmental Studies and Management, Vol. 3, No2

McLafferty, S.L (2003) GIS and Healthcare. Annual Reviews on Public Health. 2003.24:25-42. www.annualreviews.org 
Mitropoulos P, Mitropoulos I, Giannikos I. and Sissouras, A. (2006), A Biobjective Model for the Locational Planning of Hospitals and Health Centers. Health Care Management Science, 9:171-179

Nkechi, C. (2013), Spatial analysis of health care facilities in Lapai LGA, Unpublished Bsc Project, IBB University, Lapai.

Ogundare, E.I (1982), Health Care Delivery is a Success in Oyo state, Daily Sketch, October 27, p.7

Okafor, F.C., (1990), The Spatial Dimensions of Accessibility to General Hospitals and Rural Nigeria. Socio-Economic Planning Sciences, 24 (4), pp. 295-306

Olajuyin, L.O, Olayiwola, L.M and Adeyinka, S.A. (1997) Locational analysis of Health Facilities: A case study of Irewole LGA (1940-1985). Ife Planning Journal: A Journal of Ife Community Development Study Team (ICOMDEST). 1(1), 1-13

Oppong, J.R., (2007) Data Problems in GIS and Health. Retrieved from: geog.queensu.ca/h_and_e/ healthandenvir/.../OPPONG.DOC

Parker E.B and Campbell J.L. (1998) Measuring access to primary medical care: some examples of the use of geographical information systems. Health \& Place. 4(1)83-93

Perry, B., and Gesler, W. (2000). Physical Access to Primary Health Care in Andean Boliva. Social Science Medicine, 50(11)77-88

Rushton, G., and Lolonis, P. (1996) Exploratory Spatial Analysis of Birth Defect Rates in an Urban Population. Statistics in Medicine 15:717-726

Tomlin C.D. (1990) Geographic Information Systems and Cartographic Modeling, Prentice Hall

Ufua, M.E. (2002): The Use of SPOT Remotely Sensed Data for the Revision of Nigerian 1:50,000 Topographic Maps. In Uluocha, O.N. Dada, F.A.O. (eds), Maps and Resource Management Publication of Nigerian Cartographic Association P98-113

Uluocha, O.N. (2007) Elements of Geographic Information Systems. San Iroanusi Publication, Lagos

Usman, A.K and Ahmed, M. (2013) Distribution of Primary Healthcare facilities in Kano Metropolis using Geographic Information Systems. Research Journal of Environmental and Earth Sciences. 5(4):167-176

Vatsavai, R.R., Burk, T.E., Wilson, B.T., and Shekhar, S. (2000). A Web-based browsing and spatial analysis system for regional natural resource analysis and mapping. In Proceedings of 8th ACM Symposium on GIS, Washington, D.C., USA, pgs 95-101 
Wang F.H, and Luo W. (2005) Assessing spatial and non spatial factors for healthcare access: towards an integrated approach to defining health professional shortage areas, Health \& Place. 11:131-46

Wenger, E., McDermot, R., and Synder, W. M. (2002), Cultivating communities of practice: A guide for managing knowledge. Boston: Harvard Business School Press

Wilkinson, R and Marmot, M (2006), Social Determinants of Health, International Journal of Epidemiology, 35(4)1111-1112.

World Health Organization (1998), The World Health Report 1998-Life in the $21^{\text {st }}$ Century: A vision for all

World Health Organization (2000), The World Health Report 2000-Health Systems: Improving Performance

World Health Organization (2004), The World Health Report 2004-GIS and Public Health Mapping

World Health Organization (2008), The World Health Report 2008-Primary Health Care now more than ever 